\title{
STUDI PERBANDINGAN NASKAH ISLAMOLOGI TENTANG ORANG-ORANG KERAMAT PADA ZAMAN "KUWALEN" DI JAWA
}

\section{Suwedi Montana}

Keywords: philology; javanese; arab; literary; prophet; islam

How to Cite:

Montana, S. (1988). STUDI PERBANDINGAN NASKAH ISLAMOLOGI TENTANG ORANG-ORANG KERAMAT PADA ZAMAN "KUWALEN" DI JAWA. Berkala Arkeologi, 9(1), 38-63. https://doi.org/10.30883/jba.v9i1.497

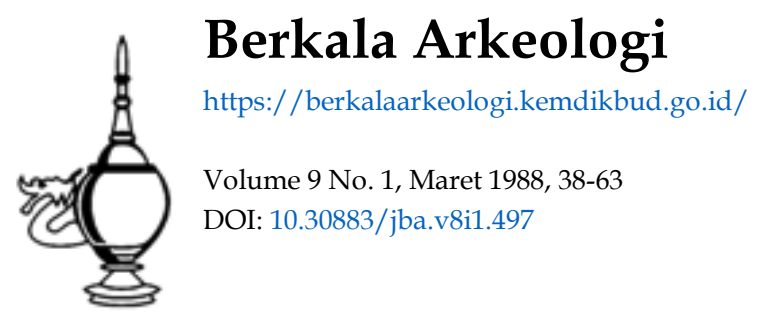




\section{STUDI PERBANDINGAN NASKAH ISLAMOLOGI TENTANG ORANG-ORANG KERAMAT PADA ZAMAN "KUWALEN" DI JAWA}

Suwedi Montana

\section{PENDAHULUAN}

Kalau masalah paleografi di Indonesia dibicarakan dalam Arkeologi, hal itu memang menarik perhatian sebab sampai batas waktu tertentu paleogram itu sudah tidak dipakai lagi, misalnya aksara Palawa, Dewanagari, Jawa Kuna, Sunda Kuna, dan Melayu Kuna. Berbicara tentang naskah islamologi rasanya lebih berbau modernisme dan kurang mencerminkan sifat arkeologis. Apalagi aksara dalam naskah islamologi sampai saat ini masih dipakai, misalnya aksara Jawa, Pegon, Arab, Jawi, Jejawen, Bali, dan Lontara. Meskipun demikian, penelitian terhadap naskah islamologi tidak hanya bertumpu pada jenis huruf yang dipakai dalam naskah, sebab penelitian itu akan mencakup berbagai aspek budaya yang pernah hidup dan pernah ada pada waktu suatu naskah ditulis atau pada waktu suatu cerita dilisankan untuk pertama kali dan kemudian beredar dari mulut ke mulut sampai akhimya dituliskan. Oleh karena itu adalah tidak aneh jika salah satu uraian tugas atau job deskripsi Bidang Arkeologi Islam ialah melaksanakan penelitian naskah islamologi. ${ }^{1}$

Pengertian naskah islamologi jelas berbeda dengan naskah Islam. Naskah Islam meliputi hal-hal yang berkaitan dengan agama Islam, huruf Arab dengan berbagai ragam bentuknya, dan sejarah perkembangan agama Islam serta lat ar belakang budaya Arab; sedang naskah islamologi selain mencakup masalah yang terdapat dalam ruang lingkup naskah Islam, juga meliputi aspek-aspek budaya suatu bangsa yang mendapat pengaruh agama Islam. Dengan demikian penelitian naskah islamologi tidak harus bersifat Arab sentris.

Dari sekian banyak naskah islamologi di Indonesia, maka naskahnaskah yang memuat riwayat tentang orang-orang keramat pada 
Zaman "Kuwalen" di Jawa termasuk dalam ruang lingkup penelitian naskah Islamologi. Orang-orang keramat itu, yang tidak lain adalah para wali, sangat besar peranannya dalam memasyarakatkan agama Islam di Jawa. Naskah yang membicarakan riwayat para wali itu ada yang bersifat khusus, yaitu membicarakan kehidupan para wali, tetapi pada umumnya cerita wali itu terdapat dalam naskah Babad, Sajarah, atau Wawacan.

Makalah ini secara singkat akan membicarakan masalah orangorang keramat dengan memperbandingkan 22 naskah yang terdiri atas 2 manuskrip dari abad XVI dan XVIII, 17 naskah milik perorangan atau yayasan, dan 3 naskah Sejarah yang memuat cerita wali di Jawa: Dari perbandingan naskah-naskah itu akan dapat diliput pembicaraan mengenai orang-orang keramat dan Zaman "Kuwalen", derajat kebenaran naskah Babad, Hagiologi Jawa, dan jumlah wali menurut berbagai naskah. Seyogyanya pembicaraan itu akan dapat berkembang lebih luas, tetapi karena terbatasnya jumlah halaman, maká barangkali rencana pembicaraan 4 sub judul itu pun tidak akan tercapai.

\section{ORANG-ORANG KERAMAT DAN ZAMAN "KUWALEN"}

Dalam Pendahuluan telah disinggung bahwa yang dimaksud dengan orangikeramat itu adalah wali. Wali berasal dari kata Arab walã yang artinya dekat; dan kata waliya berarti memerintah, mengatur, melindungi, dermawan, teman, sahabat, dan wakil. Pemakaian kata tersebut dalam konteks agama Islam sama dengaan orang suci (saint). Tetapi dalam Al Quran, wali dalam arti saint tidak kita temukan, yang ada hanya dalam arti keluarga dekat atau wakil (Surah Isrã : 33), sahabat Allah (Surah Yunus : 62), atau dengan arti Tuhan itu sendiri (Surah Al Baqarah : 257).

Menurut Jurjãnĩ dalam Ta'rifat, istilah wali sama dengan 'arif bi'illah - he who possesses mystic knowledge, he who knows God (Gibb: 1974: 629). Wali bukan saja mempunyải pengaruh karena Allah, tetapi juga memiliki anugerah keajaiban (mirakel) yaitu ka-

Berkala Arkeologi IX (1) 
ramat. la dapat mengubah diri, bepergian ke tempat yang jauh dalam waktu sekejap, berbicara dalam berbagai bahasa, menghidupkan rang mati, membuat ramalan-ramalan; semua itu karena mendapat barkah Allah. Ia dapat pula memberikan semangat dalam peperang. an, sehingga musuh dapat dikalahkan. Mirakel keramat wali itu berbeda dengan mirakel nabi yang dinamakan mu'jizat. Betapapun keramat seorang wali, kedudukannya selalu di bawah Muhammad dan nabi-nabi lainnya. Oleh karena itu kaum Mu'tazili membantah kekeramatan wali, sebab orang Muslim yang setia dan taqwa kepada Allah adalah teman Allah atau wali Allah.

Kata "kuwalen" mempunyai kaitan dengan kata wali sebab ku walen adalah kata jadian dari ka - wali - an yang bergeser bunyi. nya menjadi kewalen dan kuwalen.

Sampai akhir abad XX masyarakat Jawa masih mengenal dua periode dari masa lampau yakni Zaman Budo dan Zaman "Kuwalen". Zaman "Kuwalen" merupakan kesinambungandariZaman Budo. tetapi dua zaman itu mempunyai perbedaan yang sangat mendasar dalam agama, budaya, struktur masyarakat, konstelasi pemerintahan, dan kehidupan sosial pada umumnya. Zaman Budo adalah Zaman Pra Islam ketika agama Hindu dan Buddha menjadi dasar pijakan dalam kehidupan politik, ekonomi, sosial budaya, dan militer. Yang menarik perhatian ialah istilah yang dipakai untuk Zaman Pra Islam itu dinamakan Zaman Budo, yang mewakili dua agama, Hindu dan Buddha. Dengan istilah itu masyarakat awam di pulau Jawa pada masa itu tidak membedakan mana yang agama Buddha dan mana agama Hindu, keduanya disebut Budo.

Zaman "Kuwalen" dimulai pada waktu para wali memasyarakatkan agama Rasul atau agama Islam di Jawa antara abad XV-XVI. Dalam sejarah politik di Jawa, Zaman "Kuwalen" itu terjadi pada periode Kerajaan Demak sampai Kerajaan Pajang. Pada akhir periode Pajang, peranan dan pengaruh para wali sudah menipis, sehingga pada periode Mataram peranan dan pengaruh itu tidak tampak menonjol,karena sengaja dibatasi dan diperkecil oleh penguasa Mata- 
ram. Barangkali penguasa Mataram sudah mempelajari peranan para wali pada dua periode sebelumnya sehingga mengetahui betapa kuatnya campur tangan para wali pada pemerintahan Demak dan Pajang, yang bahkan mericampuri urusan pribadi para penguasa. Oleh karena itu, ketika pada suatu saat terjadi perselisihan yang mendasar antara penguasa Mataram dengan benteng terakhir kekuatan para wali di Giri, maka Giri dihancurbinasakan pada abad XVII oleh Mataram.

\section{DERAJAT KEBENARAN NASKAH BABAD}

Masyarakat mempunyai kepercayaan yang kuat kepada para wali sehingga menyebabkan timbulnya cerita hagiologis yang meluas. Kehidupan cerita wali itu berlanjut sampai melampaui batas wakta keberadaan para wali itu sendiri. Cerita wali dapat bertahan melebihi 4 abad,sejak dikenal oleh masyarakat pada abad XVI. Kita tidak dapat menduga sampai kapan cerita itu dapat bertahan. Cerita wali itu berkembang dari masa ke masa, sehingga antara cerita yang satu dengan yang lain selalu terdapat hal-hal yang berbeda, bergantung pada pihak penutur atau penulis cerita itu. Dalam cerita wali yang umumnya berasal dari pesisiran itu, peran seorang wali tidak selalu sama. Perbedaan ini tampak jelas dalam cerita-cerita wali versi $\mathbf{C}$ rebon yang jumlahnya cukup banyak. Apalagi perbedaan antara versi Cirebon dengan versi Gresik dan Tuban serta Babad Tanah Jawi tarnpak sangat mencolok. Perbedaan itu bukan hanya mengenai peran utama, melainkan juga menyangkut silsilah dan kehidupan keluarga tokoh tersebut. Di samping itu terdapat pula perbedaan jumlah wali dalam berbagai versi.

Pada waktu agama Islam baru menyentuh kehidupan masyarakat Jawa, peranan para wali sangat besar. Karya besar para wali itulah yang menyebabkan agama Islam hidup subur di Jawa. Berita tentang sepak terjang para wali dalam melaksanakan islamisasi terkenal di mana-mana sampai ke Indonesia Timur dan Kalimantan.2 
Cerita wali yang legendaris itu terdapat dalam berbagai naskah lama. Pada umumnya naskah yang memuat cerita wali itu merupakan penulisan sejarah lokal atau historiografi. Naskah historiografi dikenal secara tradisional sebagai Babad, sajarah, atau Wawacan. Sebagai naskah historiografi, masih perlu dipertanyakan seberapa jauh kebenaran Babad-babad tersebut. Derajat kebenaran dalam Babad memang tidak mutlak. Masing-masing Babad menunjukkan suatu aspek yang dominan, misalnya aspek militer, aspek politik, atau aspek kultural. Akan tetapi pada umumnya penonjolan aspek-aspek itu tidak dapat dipisah-pisahkan, karena mempunyai kaitan yang menjalin isi cerita secara keseluruhan. Meskipun kebenaran yang dikandung dalam Babad itu tidak mutlak, tetapi peranannya untuk mengungkap sejarah lokal masih dapat diandalkan.

Sebagai historiografi, umumnya Babad lebih banyak mengungkap hal-hal yang bersifat legendaris daripada yang bersifat faktual. Sifat-sifat itulah yang menimbulkan anggapan bahwa Babad kurang akurat untuk dipakai sebagai sumber penelitian sejarah. Hal itu memang dapat dipahami, sebab sebenarnya Babad merupakan kronik. yaitu catatan tentang kejadian historis yang tidak mengetengahkan tafsiran terhadap fakta. Penulis kronik jarang menyebut sumber informasi, tetapi sering menggunakan tradisi dan legenda tanpa memandang keotentikannya. Apabila seorang penulis kronik melukiskan tentang masanya, ia tidak selektif; ia akan melaporkan segala kejadian, baik yang faktual maupun yang aneh-aneh dalam detil yang seimbang. Jika tidak ada dokumen yang aseli, maka dalam hal ini kronik dapat bermanfaat sebagai satu-satunya sumber informasi dan dapat memberikan bukti-bukti yang dapat dinalar.

Harus dipahami bahwa penulisan Babad mempunyai tujuan ganda. Pada satu pihak Babad merupakan karya tulis yang mengungkapkan kejadian-kejadian yang dialami oleh penulisnya; atau peristiwa dalam Babad itu merupakan hasil adaptasi dari cerita yang turun-temurun. Pada pihak lain penulisan Babad merupakan upaya 
untuk mengagungkan dan memperkokoh kedudukan tokoh dalam Babad, misalnya ríja, pendeta, wali, atau panglima tentara. Di sinilah terjadi pemaksaan cerita, seperti halnya istilah pesan sponsor pada masa kini. Sehingga apabila Babad dianggap kurang akurat, hal itu amat relatif, sebab setidaknya nama tokoh, kejadian tempat, dan bahkan sering kronologinya adalah benar, hanya bumbu penceritaan itu sering mengganggu keakuratan Babad. Historiografi Jawa memang tidak jauh berbeda dengan historiografi Melayu. Perbedaan terletak pada pencantuman pertanggalan. Dalam historiografi Melayu atau hikayat, nama tokoh, tempat, dan peristiwa dicantumkan tanpa data pertanggalan. Kronologi dalam Babad tidak dalam wujud angka tahun. melainkan disamarkan dalam kata-kata atau kalimat yang dinamakan candrasangkala. Kadang-kadang kronologi itu disamarkan dalam bentuk ukiran atau gambar yang dinamakan sengkalan memet. Oleh karena itu kita tidak boleh menganggap bahwa Babad tidak mempunyai nilai sejarah. Untuk menguji kebenaran nilai itu kita harus membandingkan dengan catatan "Barat" seperti laporan tertentu dari orang Portugis dan kemudian juga dari orang Belanda (Hoesein Djajadiningrat, 1965: 77). Dalam hal ini dapat diamati karya Sir Th. Raffles dan karya-karya H.J. de Graaf mengenai sejarah Jawa, yang umumnya berdasarkan pada Babad.

Meminjam kata-kata Hoesein Djajadiningrat tentang nilai sejarah pada Babad, maka timbul pertanyaan apakah tokoh wali itu benarbenar ada. Kalau kita mengamati karya tulis wali yang berbentuk Suluk atau melihat makam dan mesjid para wali, tampaknya mustahil jika orangnya bukan tokoh penting. Hanya peristiwa legendaris yang mengelilinginya mungkin rekaan belaka, dengan maksud untuk memperkokoh kedudukan dan mengagungkan atau mempertinggi kedudukan wali itu. Contoh yang menarik tentang hal ini ialah kasus silsilah para tokoh, yang ditarik jauh ke belakang berpuluh abad yang silam. Silsilah raja-raja Melayu ditarik ke belakang sampai Sultan Iskandar Zulkarnain (Alexander Agung) dari Macedonia. Rajaraja Jawa silsilahnya ditarik sampai ke Nabi Adam, dilanjutkan kepada

\section{Berkala Arkeologi IX (1)}


tokoh-tokoh dalam Mahabharata, sampai akhimya pada Raja Mataram Islam. Demikian pula silsilah tokoh wali pada umumnya dikembalikan kepada Nabi Muhammad. Hoesein Djajadiningrat mengatakan tentang asal-usul Sunan Gunung Jati : Kita telah mengatakan bahwa mata rantai yang menghubungkan wali dengan cicit Muhammad, Zeinulabidin, telah sepenuhnya direka-reka (Hoesein Djajadiningrat, 1983: 257). Usaha untuk menarik silsilah para wali itu sampai ke Nabi Muhammad, bahkan mengembalikan silsilah orangorang yang terkenal hingga ke tanah Arab, adalah ciri khas tradisi Cirebon (Hoesein Djajadiningrat, 1983: 265).

\section{JUMLAH WALI MENURUT BERBAGAI NASKAH}

Hal yang menarik perhatian tentang wali-wali yang hidup pada Zaman "Kuwalen" ialah jumlahnya yang cukup banyak. Kita mengalami kesulitan untuk membuat garis batas antara Wali Sanga dengan wali-wali (orang keramat) lainnya. Kenyataan tentang ini dapat dilihat pada situs makam para Wali Sanga, masjid peninggalan, serta petilasannya yang masih dikeramatkan oleh masyarakat. Kepercayaan para pemuja itu amat kuat, sehingga timbul kepercayaan lain yang menyesatkan dan bertentangan dengan agama. Wali lain yang tak termasuk dalam kelompok Wali Sanga juga dipujapuja olah masyarakat, sehingga timbul pertanyaan apakah wali-wali lokal non Wali Sanga itu mempunyai derajat setara Wali Sanga. Meskipun demikian, tampaknya kedudukan Wali Sanga lebih tinggi dibanding dengan kedudukan wali lokal.

Hierarki dalam kewalian di Jawa, merupakan hal yang wajar, sebab di dunia Arab pun terdapat hirarki dan bahkan terdapat jumlah wali beratus-ratus orang. Wali yang mempunyai kedudukan tinggi ialah wali akhyar sejumlah 300 , wali abdal 40, wali abrar 7 , wali awtad 4, wali mukaba' 3, dan wali kutb atau ghawth merupakan wali yang paling unik. Wali yang paling banyak mistiknya adalah wali kutb, misalnya Juraij. Sedangkan Ibn. Masruk adalah wali awtad (pilar, penyangga). Dalam Babad Cirebon, Sunan Gunung Jati di- 
anggap sebagai wali kutb, sedang menurut tradisi Demak, yang menjadi wali kutb adalah Sunan Kali Jaga.

Menurut Doutté, hirarki kewalian ada 7 tingkat. Urutannya dari yang paling rendah adalah ${ }^{3}$ : wali nukaba' (300 wali), wali nujaba' (40 wali), wali abdal (70 wali), wali khiyar, wali abtad, wali kutub, dan yang tertinggi adalah wali ghawth. Wali khiyar adalah wali pilihan yang melanjutkan penyebaran agama Islam di dunia. Wali awtad adalah yang tinggal di empat penjuru dengan kiblat ke Mekah. Wali kutub adalah wali terbesar pada masanya, sedangkan wali ghawth merupakan wali yang memikul dosa-dosa orang yang beriman.

Di berbagai tempat dikenal sejumlah wali yang berbeda-beda, baik menurut paham Sunni maupun Shiah, dengan asal yang berbeda-beda pula. Pada umumnya para wali adalah ahli mistik, pendiri salah satu ajaran agama, nenek moyang atau kepala suku, dan pangeran atau pendiri dinasti. Selain itu para wali adalah orang fakir atau darwis, bahkan orang yang bahlul atau sebaliknya pahlawan. Dalam agama Roma Katolik, seorang wali (santo) dipuja karena ia merupakan pelindung kota, desa, perdagangan, atau pelindung perkumpulan (Gibb, 1974: 630). Wali-wali di Jawa, terutama Wali Sanga, tampaknya tidak ada yang berasal dari penduduk pribumi, kecuali Sunan Kalijaga, seandainya beliau benar trah Jawa. Selain itu juga Sunan Tembayat dan Sunan Geseng, seandainya dapat digolongkan dalam Wali Sanga. Bahkan menurut tradisi Cirebon, semua wali bukan pribumi.

Cerita tentang wali dapat ditemukan dalam naskah-naskah lama. Masing-masing naskah berbeda dalam pencantuman nama dan jumlah wali. Meskipun nama wali dalam kelompok Wali Sanga tidak selalu sama, sebutan Wali Sanga itu sangat menonjol. Masalahnya ialah mengapa kelompok itu dinamakan Wali Sanga, padahal jumlah wali yang tergabung dalam Wali Sanga lebih dari sembilan.

Angka mempunyai kedudukan tersendiri dalam masyarakat. Hampir semua kegiatan yang dianggap penting dalam masyarakat 
Jawa selalu didasarkan pada perhitungan atau petangan, misalnya kelahiran, kematian, pindah rumah, pengantin, dan bahkan perbuatan yang buruk seperti mencuri. Penggunaan jumlah sembilan untuk menamakan kelompok Wali Sanga itu berakar pada pandangan hidup orang Jawa tentang kosmos. Baik dalam mikro maupun makro kosmos, jumlah sembilan mempunyai kedudukan penting. Dalam kitab Tatacara dijelaskan bahwa dalam mikrokosmos terdapat unsurunsur yang dalam satu hari keluar bersama déngan bayi-dari rahim ibu. Unsur itu dikenal sebagai papat genep kalima pancer atau empat genap yang kelima satu dan ditambah dengan empat unsur lainnya menjadi sembilan. Empat unsur lain yang tak terpisahkan dengan sang bayi ialah bayangan (Padmasusastra, 1980: 219). Pandangan lain terhadap mikrokosmos juga didapatkan pada nawa sanga atau babahan nawa sanga.

Pandangan tentang mikrokosmos yang bersumber pada papat genep kalima pancer dan babahan nawa sanga itu berkembang pada masa sebelum Islam, bahkan sebelum kebudayaan Hindu dan Buddha menjadi dasar pegangan hidup. Meskipun dalam agama Hindu terdapat juga pandangan tentang nawa sanga, tetapi berbeda dengan nawa sanga Jawa. Nawa sanga Hindu yang sudah diserap dalam budaya Jawa tetap diterapkan pada makrokosmos. Dalam pandangan itu seorang dewa bertempat tinggal di pusat, membawahi delapan dewa lainnya yang tinggal di delapan penjuru mata angin. Warna-warna utama, logam, profesi, dan berbagai konsepsi tentang benda diasosiasikan pada dewa-dewa, misalnya warna putih, perak, air, dan angin diasosiasikan dengan timur beserta dewa pelindungnya. Ide utama kadang-kadang digolongkan dalam lima kelompok, yaitu pusat tambah empat, sering pula dalam kelompok sembilan (Rani, 1957 : 357). Bandingkan pandangan ini dengan papat genep kelima pancer. Jadi nawa sanga merupakan sistem sembilan dewa, delapan dari mereka berada di delapan penjuru dan dewa utama berada di pusat. Nawa sanga merupakan penempatan satu dewa dan delapan manifestasinya. Sistem seperti itu juga terdapat dalam agama Buddha Mahayana, yang dikenal dengan pola mandala. 
Dengan memperhatikan pentingnya kedudukan angka sembilan dalam pandangan hidup orang Jawa, maka tidak mustahil jika para wali juga menggunakan jumlah sembilan sebagai kelompok. Tidak mustahil pula bahwa Wali Sanga merupakan lambang suatu dewan wali, dengan mengambil angka sembilan yang pada masa sebelum Islam merupakan angka keramat (Sartono Kartodirdjo, 1976 : 117), dan bukan mustahil pula bahwa sebutan Wali Sanga merupakan lambang yang bermakna bahwa para wali merupakan sumber kebajikan dan sumber siar agama Islam ke delapan penjuru tanah Jawa, dengan para wali itu sendiri sebagai pusatnya. Oleh karena itu, meskipun jumlah kelompok tersebut tetap sembilan, tetapi tokohnya dapat berganti-ganti.

Untuk mengetahui jumlah dan nama-nama wali di Jawa kita perbandingkan 19 historiografi, 2 buah karya orang asing, dan 1 buah naskah karya ahli-ahli kita sendiri. Di bawah ini uraian singkat dari naskah-naskah tersebut.

1. Naskah yang dianggap tua adalah Musyawaratan Para Wali (MPW), yang ditulis abad XVI dan berhuruf Jawa. MPW diadakan di Giri Gajah pada hari Jumat tanggal 5 bulan Ramelan tahun Wawu (Drewes, 1978: 44). Wali yang disebut di dalamnya adalah: Pangeran Bonang, Pangeran Majagung, Pangeran ing Cerebon, Pangeran ing Kali Jaga, Sek Bentong, Molana Magribi, Sek Lemah Bang, dan Pangeran Giri Gajah ing Gunung. Jumlah wali hanya delapan orang.

2. Dua naskah Babad Tanah Jawi (BTJ), yaitu versi prosa dan versi tembang atau versi Purworejo. Antara versi prosa (BTJ1) dan versi tembang (BTJ2), terdapat beberapa perbedaan. Menurut BTJ1 hanya terdapat 8 orang wali, sedang menurut BTJ2 jumlah wali adalah 16 orang. Meskipun jumlah wali dalam BTJ2 16 orang, tetapi sebutan Wali Sanga tetap dipakai, seperti yang dapat dilihat pada pupuh 41 .

seh siti jenar kesti (Seh Siti Jenar sesungguhnya) mrengkang saking wali sanga (memberontak dari Wali Sanga). 
Gelar yang dipakai oleh wali-wali itu tidak seragam, misalnya saja Sunan, Pangeran, Seh (Sek), Ki Ageng, dan Molana.

3. Dari Banten terdapat 2 naskah Sajarah Banten (SBT), yaitu Sajarah Banten Rante-rante (SBT1) dan Naskah tak berjudul dari abad XVIII (SBT2). SBT1 mencantumkan 11 wali dan SBT2 memuat 12 wali.

4. Dari tradisi Cirebon digunakan 5 naskah yang saling berbeda. Dalam Pupuh 31 Babad Cirebon milik Tarya di Tjakrapura (BC1) dikisahkan tentang episoda ketika orang-orang keramat dari tanah Jawa bersembahyang bersama di Mekah, kemudian diputuskan pemberian gelar (tidak jelas siapa yang memberikan gelar) yang dibacakan oleh Pangeran Tuban. Gelar itu diberikan kepada 10 orang keramat tersebut. Dalam BC2 koleksi Bataviaasch Genootschap No. 585 halaman 185 terdapat urutan nama wali sebanyak 11 orang. Nama-nama sebagian wali sama dengan yang terdapat pada naskah yang lain, tetapi sebagian ada yang tidak disebut. Dalam BC3 koleksi Bataviaasch Genootschap No. 548 halaman 146 terdapat episoda : Wali sembilan berkumpul bersama pada hari Jumat tanggal 5 bulan Puasa, wong sanga dadya siji (orang sembilan menjadi satu). Ternyata yang dimaksud dengan sembilan orang menjadi satu, terdiri atas 13 orang, baik nama baru maupun nama lama. Dalam BC4 koleksi Bataviaasch Genootschap No. 518 halaman 74 juga terdapat urutan nama wali: waliulla sasanga nusa Jawi (sembilan wali tanah Jawa) yang dipimpin oleh Sunan Gunung Jati. Sebaliknya dalam BC5 (Pigeaud, 1911: 194). pada Pupuh XXIII terdapat urutan nama wali sejumlah 10 orang. Dalam urutan itu nama yang sangat populer yaitu Sunan Kalijaga tidak dimunculkan.

5. Naskah tulisan tangan pada kertas daluang milik Kepala Seksi Kebudayaan Tuban. Naskah tersebut sudah rusak tidak berjudul, berhuruf Pegon, bentuk tembang Macapat, dan diberi kode NTB. Melihat bahasa, huruf dan kertas yang digunakan, diperkirakan 
NTB berasal dari abad XVI. Dalam NTB nama-nama wali memang dikelompokkan, misalnya yang terlihat pada episoda wafatnya Sunan Ampel :

Ganti yang diceritakan, maka Sunan Ngampel pun wafat. Semua wali hadir bersholat. Yang menjadi imam Sunan Giri, semua wali menjadi makmum. Setelah mayat dishalatkan maka 'sinarèkaken' di bagian utara pendapa. 'Pêpêkan' (lengkap) para wali semua :

Jumlah wali termasuk Sunan Ampel adalah 12 orang. Hal yang menarik ialah bahwa nama Seh Mlaya ternyata tidak sama dengan Sunan Kali Jaga yang selama ini dianggap satu orang.

6. Dalam Babad Demak (BD) jumlah dan nama wali lebih menarik lagi. Dalam Pupuh XLIV pada (bait) 28, 29 dicantumkan kelom. pok wali. Ketika itu para wali sedang berkumpul di mesjid, mereka terdiri atas 12 orang. Dalam Pupuh LIII : $11-24$ terdapat episoda musyawaratan para wali di mesjid Demak. Musyawarah itu diadakan karena Seh Siti Jenar dianggap meninggalkan sarak. Jumlah wali juga 12 orang. Ternyata dari 2 kelompok wali dalam naskah yang sama terdapat perbedaan nama anggota kelompok wali. Selain tokoh-tokoh itu disebut juga tokoh Sunan Sendang atau Supa sebagai wali (lihat Pupuh LI : 38).

7. Dalam naskah dari Jawa Barat (NJB) Cod or 7406 halaman 11 terdapat juga episoda tentang Wali Sanga yang berjumlah 9 orang.

8. Naskah yang banyak membicarakan sejarah Jawa adalah Serat Kanda (SKD) ditulis antara abad XVI-XVII dalam bahasa pesisiran. Dalam SKD Mayor ada episoda musyawaratan para wali setelah Sunan Ampel wafat pada tahun awak kalih guna iku (13 21). Wali yang hadir 9 orang, sehingga jumlah keseluruhan dengan Sunan Ampel adalah 10 orang.

9. Dalam Serat Centini (SCN) yang ditulis pada 26 Sura 1742 AJ, cerita tentang wali terdapat dalam jilid 1 dan 3. Pada SCN1 
terdapat episoda ketika Sunan Bayat bercerita kepada murid. nya, Seh Sekar Dalima dari Gunung Slamet (putra raja Majapahit) tentang musyawaratan wali di Giri Gajah. Jumlah wali ada 12 orang. Bandingkan dalam MPW yang bermusyawarah 8 wali. Dalam SCN3 Pupuh 195 : 7 terdapat 2 kelompok wali, masing-masing hidup pada periode Demak dan Pajang. Wali pada periode Demak berjumlah 8 orang, dan pada periode Pajang juga 8 orang. Nama yang menarik perhatian adalah Seh Molana dan Molana Magribi yang orangnya berlainan.

10. Tiga naskah (N1, N2, N3) koleksi Leiden University Library Oriental Department (LOr). N1 (LOr 6551) milik Muhammad Saleh, Karangduren, Purbalingga, memuat daftar wali sebanyak 9 orang. N2 (LOr 7453) memuat catatan tentang mistik, martabat pitu, serta aksara dan pandangan para wali. Jumlah wali ada 12 orang. N3 (LOr 1911) selain memuat masalah teologi Islam juga memuat pandangan 13 orang suci.

11. Dalam Puuh VII : 14 dari Suluk Seh Siti Jenar (SSJ) terdapat episoda tentang penguburan Seh Siti Jenar. Diceritakan bahwa pepak wali sanga (lengkap wali sanga) menyelenggarakan mayat Siti Jenar. Ternyata yang dimaksud dengan wali sanga lengkap itu ternyata hanya 8 orang. Memang dengan Siti Jenar jumlahnya menjadi sembilan.

12. Dalam History of Java II, 1817 (RAF) pada halaman 124-125 diceritakan bahwa tak lama setelah dimulai pembangunan mesjid Demak maka Sunan Ampel sakit. Setelah Sunan Ampel meninggal, Raden Patah bersama para Sunan kembali ke Bintara dan melanjutkan pembangunan mesjid. Mereka, tidak termasuk Sunan Ampel, berjumlah 8 orang. Peristiwa itu terjadi pada 1390 AJ.

13. Wali yang dikenal dalam Land en Volk van Java I karya C. Lekerkerker (LEK) ada 14 orang. Nama yang menarik adalah Malik Ibrahim yang sama dengan Molana Magribi, dan muncul tokoh baru yaitu Seh Abdul Muhyi. 
14. Dalam Sejarah Nasional Indonesia III (SN) tidak ada urut-urutan nama wali tetapi secara terpisah dalam berbagai peristiwa terdapat juga nama-nama wali sejumlah 9 orang.

Apabila wali-wali dalam 22 sumber data tekstual itu dijumlahkan, akan ditemukan lebih dari 100 wali. Meskipun nama yang sama tidak dihitung, akan didapatkan berpuluh-puluh wali. Oleh karena itu perlu dievaluasi misalnya tokoh yang mempunyai persamaan tempat, persamaan masalah, persamaan waktu, dan persamaan lainnya tetapi dengan nama yang berbeda, kemungkinan orangnya sama, misalnya Sunan Gunung Jati, Pangeran Cerbon, Sunan Agum of Cheribon, Seh Nurullah, dan Sunan Purba adalah satu orang.

\section{DAFTAR NAMA DAN JUMLAH WALI MENURUT BERBAGAI SUMBER}

\section{MPW}

1. Pangeran Bonang

2. Pangeran Majagung

3. Pangeran Cerebon

4. Pangeran ing Kali Jaga

5. Seh Bentong

6. Molana Magribi

7. Seh Lemah Bang

8. Pangeran ing Giri Gajah

2. BTJ1
1. Sunan Ampel
2. Sunan Giri
3. Sunan Kudus
4. Sunan Kali
5. Seh Siti Jenar
6. Molana Brahim Asmara
7. Ki Ageng Sela. 
3. BTJ2
1. Sunan Kali Jaga
2. Sunan Kudus
3. Sunan Purwaganda
4. Sunan Giripura
5. Pangeran Gunung Jati
6. Pangeran Tembayat
7. Pangeran Majagung
8. Pangeran Pangalasan
9. Pangeran Kaos
10. Pangeran Palembang
11. Seh Siti Jenar
12. Sunan Bonang
13. Seh Mlaya
14. Pangeran Ngudung
15. Pangeran Modang
16. Sunan Geseng.

\section{SBT1}

1. Pangeran Kali Jaga

2. Molana Bagdad

3. Molana Rahmat

4. Sunan Gunung Jati

5. Sunan Bonang.

6. Sunan Giri

7. Sunan Kudus

8. Seh Majagung

9. Molana Magrib

10. Seh Bentong

11. Seh Lemah Bang.

\section{SBT2}

1. Pangeran Rahmat

2. Pangeran Bonang 
3. Pangeran Darajat

4. Pangeran Giri Kadaton

5. Pangeran Karang Kamuning

6. Seh Nurullah

7. Mahdum Sampang

8. Kiyahi Wurayapada

9. Kiyahi Gedeng Palembang

10. Kiyahi Gedeng Kali Jaga

11. Pangeran ing Kudus

12. Pangeran Palalangon.

\section{NTB}

1. Sunan Ampel Denta

2. Sunan Bonang

3. Sunan Giri

4. Sunan Kali Jaga

5. Sunan Darajat

6. Sunan Gunung Jati

7. Sunan Murya

8. Sunan Kudus

9. Sunan Wilis

10. Sunan Miweran

11. Sunan Demak

12. Sunan Ngudung

13. Sunan Melaya

14. Sunan Kertayasa

15. Seh Siti Jenar

7. $\mathrm{BC} 1$

1. Kangjeng Sinuhun Cerebon

2. Sultan Giri Gaja

3. Kangjeng Sunan Bonang

4. Sunan Jelang

5. Susuhunan Bentong.

6. Sunan Kudus 
7. Sunan Kadaton

8. Sunan Sasmita

9. Sunan Kajamus

10. Sunan Adi

11. Pangeran Mahdum

12. Pangeran Tuban

8. BC2

1. Sunan Giri

2. Seh Siti Jenar

3. Sunan Kali Jaga

4. Sunan Wuryapada

5. Pangeran Cerebon

6. Pangeran Tembayat

7. Pangeran Giri Gajah

8. Pangeran Majagung

9. Pangeran Kaos

10. Pangeran Palembang

11. Seh Molana Magribi

9. $\mathrm{BC} 3$

1. Pangeran Bonang

2. Pangeran Kali Jaga

3. Mulana Rum

4. Seh Bentong

5. Sunan Welang

6. Pangeran Jarakan

7. Pangeran Giri Kedaton

8. Pangeran Jagung

9. Seh Magrib

10.. Seh Lemah Bang

11. Sunan Purba 


\section{BC4}

1. Seh Lemah Bang

2. Molana Magrib

3. Sunan Jati

4. Santri Kudus

5. Sunan Kali

6. Sunan Bonang

7. Seh Bentong

8. Seh Majagung

9. Sunan Giri

\section{1. $\mathrm{BC} 5$}

1. Sunan Darajat

2. Molana Magribi

3. Sunan Bonang

4. Sunan Giri

5. Sunan Gunung Jati

6. Sunan Kudus

7. Pangeran Majagung

8. Seh Bentong

9. Seh Lemah Bang.

12. $\mathrm{BD}$
1. Raden Rahmat
2. Prabu Satmata
3. Seh Bentong
4. Mulana Iskak
5. Sunan Bonang
6. Sunan Gunung Jati
7. Seh Mulana Magribi
8. Seh Mlaya
9. Seh Siti Jenar
10. Pangeran Cerebon
11. Pangeran Palembang
12. Sunan Ngudung 
13. Sunan Ngatas Angin

14. Sunan Wuryapada

15. Seh Mulana

16. Pangeran Bayat

17. Seh Domba

18. Sunan Geseng

19. Pangeran Kudus

20. Seh Majagung

21. Sunan Sendang

\section{NJB}
1. Pangeran Bonang
2. Pangeran Majagung
3. Pangeran Cerbon
4. Seh Lemah Abang
5. Seh Bentong
6. Molana Magribi
7. Sunan Ampel Denta
8. Sunan Giri
9. Sunan Kali Jaga

4. SKD
1. Sunan Ampel
2. Sunan Giri
3. Sunan Cerbon
4. Sunan Geseng
5. Sunan Majagung
6. Seh Lemah Bang
7. Sunan Undung
8. Sunan Bonang
9. Sunan Darajat
10. Sunan Kali Jaga 
15. SSJ
1. Seh Siti Jenar
2. Sunan Bonang
3. Sunan Kali Jaga
4. Pangeran Bayat
5. Jeng Magribi
6. Pangeran Ngudung
7. Pangeran Modang
8. Sunan Geseng
9. Seh Molana

16. $\mathrm{SCN}$
1. Suhunan Bayat
2. Prabu Satmata
3. Suhunan Benang
4. Suhunan Kali Jaga
5. Suhunan Ngampel Denta
6. Suhunan Kudus
7. Seh Siti Jenar
8. Seh Bentong
9. Pangeran Palembang
10. Seh Molana
11. Molana Magribi
12. Panembahan Madura.

Periode Demak

13. Kangjeng Suhunan Giri Kedaton

14. Kangjeng Suhunan ing Tandes

15. Kangjeng Suhunan ing Majagung

16. Kangjeng Suhunan ing Benang

17. Kangjeng Suhunan ing Wuryapada

18. Kangjeng Suhunan ing Kalinyamat

19. Kangjeng Suhunan ing Gunung Jati

20. Kangjeng Suhunan Kajenar. 
Periode Pajang

21. Kangjeng Suhunan Giri Prapen

22. Kangjeng Suhunan ing Darajat

23. Kangjeng Suhunan Ngatasangin

24. Kali Jaga

25. Kangjeng Suhunan ing Tembayat

26. Kangjeng Suhunan ing Padusan

27. Kangjeng Suhunan ing Kudus

28. Kangjeng Suhunan Geseng.

17. N1

1. Suhunan Bonang

2. Suhunan Majagung

3. Suhunan Cerbon

4. Seh Lemang Abang

5. Seh Bentong

6. Seh Molana Magribi

7. Suhunan Ampel Denta

8. Suhunan Giri

9. Suhunan Kali Jaga

18. N2

1. Suhunan Bonang

2. Suhunan Kali Jaga

3. Suhunan Kudus

4. Suhunan Cerbon

5. Pangeran Tembayat

6. Pangeran Pakaos

7. Suhunan Gunung Jati

8. Suhunan Palembang

9. Seh Lemah Bang

10. Pangeran Kajoran

11. Suhunan Iman

12. Suhunan Seh Nur Iman 
19. N3
1. Pangeran Bonang
2. Pangeran Kali Jaga
3. Pangeran Cerbon
4. Pangeran Giri Gajah Kedaton
5. Pangeran Giri Kedaton
6. Pangeran Adilangu
7. Pangeran Kudus
8. Pangeran Lemah Abang
9. Pangeran Alas
10. Pangeran Majagung
11. Pangeran Tembayat
12. Pangeran Palimbang
13. Pangeran Pahus

\section{RAF}

1. Sunan Ampel

2. Sunan Bonang of Tuban

3. Sunan Undung of Kudus

4. Sunan Giri of Gresik

5. Sunan Agum or Mulana Jumadil Kubra of Cheribon

6. Sunan Draja of Sidayu

7. Sunan Kali Jenar

8. Sunan Kali Jaga

9. Sunan Tanggung of Tegal.

\section{LEK}

1. Sunan Ampel atau Raden Rahmat

2. Malik Ibrahim atau Molana Magribi

3. Sunan Giri atau Raden Paku

4. Sunan Drajat putra Sunan Ampel

5. Sunan Bonang atau Mahdum Ibrahim

6. Sunan Murya putra Pangeran Gadung

7. Sunan Kali Jaga atau Sunan Lepen

8. Sunan Gunung Jati asal Pase 

9. Seh Abdul Muhyi
10. Siti Jenar
11. Sunan Geseng
12. Sunan Panggung
13. Sunan Kudus
14. Sunan Ngudung
15. Sunan Tembayat.

\section{2. $\mathrm{SN}$}
1. Sunan Ampel
2. Sunan Giri
2. Sunan Bonang
4. Sunan Kali Jaga
5. Sunan Gunung Jati
6. Sunan Kudus
7. Sunan Drajat
8. Sunan Murya
9.. Sunan Panggung.

\section{PENUTUP}

Masalah wali memang menarik, sebab berbicara tentang wali berarti kita sudah memasuki masalah Sejarah Jawa pada kurun waktu tertentu. Ajaran para wali yang dikenal sebagai suluk masih relevan untuk pendidikan moral pada masa sekarang. Kepercayaan masyarakat terhadap wali juga masih tebal, sehingga sebenarnya masalah wali Jawa itu tak habis-habisnya.

Makalah ini masih dapat dikembangkan lebih luas sebab masalahnya memang belum selesai. Belum diungkapkan apakah cerita wali Jawa itu merupakan penulisan hagiologis atau hagiografis. Masalah tokoh wali secara perorangan juga belum diungkapkan, termasuk ajarannya, konflik antar pribadi, konflik ideologi, dan lainlain lagi. Kasus yang menonjol, misalnya konflik antara Siti JenarSunan Panggung dengan para wali lainnya. Apakah masalah itu bukan masalah yang mendasar antara mazhab Sunni dengan Shii 
atau pemindahan al Hallaj-Ibn Arobi ke tanah Jawa, atau masalah unio mystica pada umumnya. Bahkan masalah itu kemungkinan merupakan konflik antara agama Islam dan Javanisme. Masalah terakhir yang tidak kurang pentingnya untuk diungkapkan lebih lanjut ialah peranan para wali itu sendiri dalam islamisasi di Jawa, apakah dengan kekuatan bala tentara, dengan damai, penetration pacifique, difusi, sinkretisme atau akulturasi.

\section{Catatan kaki:}

1. Surat Keputusan Menteri Pendidikan dan Kebudayaan No. 001/0/1982.

2. Di Kalimantan Selatan terdapat cerita tentang wali dan islamisasi di Jawa serta beberapa wali Allah yang terlibat dalam islamisasi itu. Dalam Hikayat Banjar diceritakan tempat yang mula-mula menjadi muslim yaitu desa dekat Ampel Gading, selanjutnya berturut-turut desa Jipang, Gresik, Surabaya, Demak, Kudus dan seterusnya seluruh Tanah Jawa. Tentang tokoh wali hanya disebut Raja Bungsu, anak Raja Bungsu yang bernama Pangeran Bonang, anak bungsu Raja Bungsu yang kawin dengan Sunan Kudus dan anak angkat Nyai Suta Pi natih yang bernama Sunan Giri (J.J. Ras, 1968 : 424-426). Mungkin penyusun Hikayat Banjar ketika menulis tentang episoda tentang wali itu hanya mendengar dari cerita yang tidak lengkap. Tetapi yang jelas bahwa wali yang dikenal dalain Hikayat Banjar hanyalah Raja Bungsu yang ternyata ayah Sunan Bonang, jadi Raja Bungsu sama dengan Sunan Ampel Denta. Wali lain yang dikenal hanya Sunan Kudus dan Sunan Giri.

3. Doutte : L'Islam Algirien en la'n 1900, 1900. 


\section{DAFTAR PUSTAKA}

Brandes. J.1 1890: Pararaton. VBG XLIXI Batavia.

Drewesı G.W.J.1 1927. Het Document uit den Brandstappel. Djawa VIIı Solo.

Drewesı G.W.J.1 1954: Een Javaanse Primbon uit de Zestiende Eeuwı Leiden.

Drewesı G.W.J.11966: The Struggle between javanism and Islam as illustrated by Serat Dermagandul. BKI 122 i'S -Gravenhage.

Drewesı G.W.J.1 1978: An Early Javanese Code of Muslim Ethics. The Hague.

Doutteı 1900: L'/slam Algerien en l'an 1900. Algiers.

Gibbı H.A.R. \& Kramersı J.H.ı 1974: Shorter Encyclopaedia of Islam. Leiden.

Gonda! J.1 1973: Sanskrit in Indonesia. New Delhi.

Gopinatha Rao T.A.1 1916: Elements of Hindu Iconography II Part l Nadras.

Hoosein Djajadiningratı 1965 : Local Tradition and the Study of Indonesian History dalam An Introduction to Indonesian Historiographyı New York.

Hoosein Djajadiningratı 1983 : Tinjauan Kritls Tentang Sejarah Banten. Djembatan.

Ki Padmasoesastraı 1980 : Tatacara. Balai Pustaka Jakarta.

Lekerkerkerı C.1 1938: Land en Volk van Java I. Groningen.

Lekerkerkerı C.I 1938: Naskah dari Banten, abad XVIII (tulisan tangan).

Lekerkerkerı C.1 1938: Naskah dari Tuban, abad XVI (tulisan tangan).

Otthofı W.L. 1941 : Poenika serat Babad Tanah Djawi wiwit saking Nabi Adam doemoegi ing taoen 1647. 'S-Gravenhage.

Pakubuwana V1 1985: Serat Centini 1-111 Yogyakarta.

Pigeaudı Th.1 1911 : Babad Cerbon. VBG LIX. Batavia.

Pigeaudı Th.1 1933 : De Serat Tjabolang en Tentini. VBG LXXII. Batavia.

Pigeaudı Th.1 1968 : Literature of Java II \& III. The Hague.

Poerbatjarakaı 1938: De geheime leer van Soenan Bonang (Soeloek Woedjil). Djawa XVIII Jogjakarta. 
Raffles, S. Th. 1817. History of Java Il. London.

Rani. Sharada, 1957 . Slokantara, an old Javanese didactic text. New Delhi.

Ras. J.J., 1968 . Hikajat Bandjar. The Haque.

Rinke s, D.A., 1910 . De Heiligen van Java I. De maqam van Sjeh Abdoel Moehji. TBG LII, Batavia.

Rinke s, D.A., 1911 . De Heiligen van Java II. Seh Sitr,enar voor de inquisitie, TBG LIII, Batavia.

Rinke s, D.A., 1911 . De Heiligen van Java III. Soenan Geseng, TBG LIII, Batavia.

Rinke s, D.A., 1911 . De Heiligen van Java IV Ki Pandan Arang te Tembajat. TBG LIII, Batavia.

Rinke s, D.A., 1912 . De Heiligen van Java V. Pangeran Panggoeng zijne honden en het wajanspel. TBG LIV. Batavia.

Rinke s, D.A., 1913 . De Heiligen van Java VI. Het graf te Pamlaten en Hollandsche heerschappij. TBG LV. Batavia.

Sartono Kartodirdjo, 1976. Sejarah Nasional Indonesia Ill. Jakarta .

Slamet Riyadi, 1981 . Babad Demak 1. Jakarta.

Snodgrass, Adrian. 1985. The Symbolism of the Stupa. New York.

Soebardi., 1975. The Book of Cabolek. The Hague.

Soewignyo, 1978 . Kiyahi Pandhanarang . Jakarta.

Suhatmaka. 1981 . Ringkasan Serat Centini (Suluk Tambanglaras). Balai Pustaka, Jakarta.

Sutarti, 1981 . Suluk Seh Sitijenar. Jakarta. Tan Koen Swie. 1920. Babad Toeban. Kediri.

Uka tjandrasasmita, 1975 . Islamic Antiquities of Sendanngudhwur. Jakarta. 